Original scientific paper

UDK: 327:321.01

DOI: $10.5937 / J R S 1802179 \mathrm{R}$

Received: 27 August 2018 / Accepted: 19 November 2018

\title{
Small States in World Politics: State of the Art
}

\author{
JELENA RADOMAN* \\ University of Belgrade, Faculty of Political Sciences, Serbia
}

\begin{abstract}
In the literature review to follow I will first provide an overview of the major efforts in small states studies, concerning most importantly the definition of 'smallness' as the area in which an agreement is yet to be reached. This will be followed by an overview of the scholarly discussions on smallness and power and strategies that small states employ to mitigate their material limitations, which have led scholars to question the concept of power. This raised the following question: are small states permanently locked into a power hierarchy which they cannot escape, or do they have a possibility to overcome their material limitations by shaping and re-shaping relations in which they are found? Constructivists moved the debate away from structural variables and limitations that these states are faced with, and brought into the picture the small states' possibilities and different roles they might employ, thus bypassing the limitations emerging from the 'small $v s$. big powers' dichotomy. Theories of alliances, however, continue to picture the choices that are presented to small states as only two: to seek protection of bigger states or risk standing alone. Least work has been done on where and how smallness matters and where opportunities for small states lie. Future work should reflect if, when, and how 'smallness' is a factor in these states' foreign policies and their alignment politics.
\end{abstract}

Keywords: small states, power, neutrality/non-alignment, alliances, strategy.

\section{Introduction}

With the de-colonisation movement, secession wars and disintegration of former federal states such as Yugoslavia and the Soviet Union, the 20th century brought a proliferation of small states into the world politics. Understood in the traditional sense, based on the size of their territories and populations, most of today's states are small, and scholars from various theoretical backgrounds who work on International Relations and Security Studies are attempting to catch up with their growing number. Most of the time, they discuss a very basic question - What is a small state? - prior to making room for more in-depth research on what their smallness implies in the foreign-policy conduct, whether there are differences between big and small states' policy-making, and what smaller counterparts can do in the complex security agenda of the 21 st century.

There can be many starting points for research on small states. I have encountered the body of knowledge presented in this article while researching military neutrality and non-

*jelenaradoman01@gmail.com 
alignment. Reviewing the discussions on why states decide to stay outside of military alliances, I found a strong connection between neutrality/non-alignment and small states research. The review showed that there is a strong link between research of these security policies and the small states' security strategies. ${ }^{1}$ Neutrality and non-alignment have been discussed mostly as policies available to and used by small states, or, as in the case of the Non-Aligned Movement, of newly emerged states that were not necessarily small in terms of their populations and the size of their territories. However, in the course of their discussions, scholars interested in the topic have failed to make any significant contribution to the development of the concept or theory of non-alignment, and have only sporadically contributed to a broader and conceptually more informed discussion on small states.

While neutrality and non-alignment have been discussed to a certain extent in the 20th century, extensive interest in small states seems to have emerged a bit later. Robert Keohane finds this link to be the reason why small states have not been an object of systemic research for a long time. According to him, it is because the study of non-alignment served as a substitute for in-depth interest in small states. ${ }^{2}$ In David Vital's account, if we are to study genuine foreign policy performance of small states, then we should look at those that stayed outside of the formal alignment. He claims that it is exactly the small states that stand alone, especially in most critical situations that are a limiting case and represent a paradigm of small states studies. According to him, only in such cases would students be able to research the full consequences of their smallness and the limitations of their resources. ${ }^{3}$ Having reviewed the small states literature in 1975, Peter R. Baehr found it rudimentary, ascribing this to the insufficiency of the concept of small states as an analytical tool. He found scholars' attempts to define small states to be an inadequate tool for narrowing down the too-broad category of small states, which made the concept inapplicable and the entire study of small states insufficiently grounded. ${ }^{4}$

In this article I will first provide an overview of the attempts to define smallness, which has so far consumed most of the energy that was invested into small states research, and will proceed with a discussion of how that research led to the re-examination of the concept of power. My main research questions are: what is the current state of affairs and what crucial points have emerged from the existing body of work? The latest discussions on the topic of smallness and power have shown that it is possible for small states to bypass their apparent limitations and shape their foreign policies in a manner that is different or even more advanced than that of their larger counterparts. My argument is that this point, which had not been taken any further, carries with it a significant potential for future research, both on small states and foreign policy-making in general. Students of small

1 Selected literature on neutrality and non-alignment: Ørvik 1971; Baker Fox 1959; Ogley 1970; Karsh 1988; Burton 1965; Binter 1985; McSweeney1987; Wolfers 1962; Joenniemi 1988.

2 Keohane 1969; Rickli 2008; Bauwens, Clesse and Knudsen 1996; Joenniemi 1993.

3 Vital 1967.

4 Baehr 1975. 
states have not actually showed how and when smallness matters, and what is different in the small states' foreign and security policy-making compared to the same enterprise of other states. An example of this is a research on small states and alliances which failed to show any rationale behind the small states' strategies other than seeking the protection of big powers or risking standing alone. This is where opportunities for further work lie.

\section{Definitions of 'Smallness'}

In the discussions on small states much energy had been invested in the problem of defining and setting up the criteria for 'smallness'. However, neither a consensus nor a generally satisfactory definition had been reached. There are two broad categories of attempts to explain what we are actually discussing when studying small states. They can be labelled as absolute and relative definitions. The first category includes all the attempts to define which states are small and which are not by defining thresholds of material and human power that have to be reached if a state is not to be defined as small. In that respect, Vital proposes a classification of small and big states by defining the upper limits of the definition of small states: 10-15 million inhabitants in case of economically advanced countries, and 20-30 million in case of under-developed countries.

The second group of definitions, which is much more interesting, attempts to explain what constitutes 'smallness' by looking at the actor, a state, relative to the other actors in the international arena. Robert L. Rothstein makes a case for this type of definition by claiming that small states are those that - in the opinion of their leaders - are not able to secure their safety on their own. ${ }^{5}$ Similar to this, Keohane bases his definition on the claim that small states are those which are incapable of making a significant impact on the international system and whose leaders are aware of this fact. Although critical of Rothstein's attempt to classify states according to their self-perception, Keohane in fact introduces a psychological element into his definition - self-perception. However, he rejects feelings of insecurity as a distinguishing variable, since in the nuclear era insecurity is common to all states, and absolute security is out of reach even for those that are the most powerful. In his opinion, the distinguishing variable is the states' perception of whether they are able to create an impact within the international system, alone or in a group of other states. Accordingly, there are four categories of states, and small states are those whose leaders perceive themselves as fully incapable of affecting the system in any significant manner, either alone or acting in a small group. ${ }^{6}$ Tom Long also abandons the size of a state as a guide toward constructing the concept of small states. According to him, instead of focusing on their size we should look into different relations states are found in, and their dynamics. The multifaceted character and disparities of power, he argues, structure relations and influence construction of interests of both strong and weak

\footnotetext{
5 Rothstein 1968.

6 Keohane 1969, 296.
} 
actors in asymmetrical relations. ${ }^{7}$

Instead of focusing on power dynamics and discussing 'smallness' in terms of capacities and capabilities, constructivists propose looking into the discursive practices of 'smallness', as different interpretations do not necessarily tell the story of the states' 'smallness' in terms of inadequate resources and hampering conditions. ${ }^{8}$ According to them, states could embrace different narratives that might present 'smallness' as an advantage or an asset in international relations. This would lead to different policy options becoming available for (those) small states.

Self-perception and the level of states leaders' ambitions are important elements of the second group of definitions. Volker Krause and J. David Singer adopt a definition which, in their vocabulary, defines small states, e.g. minor powers as states whose diplomatic and material resources are so limited that they have to concentrate their efforts on safeguarding territorial integrity rather than pursuing more far-reaching goals. ${ }^{9}$

Vital also makes a case in this group of definitions by proposing a classification of states into three groups, specifically those of primary, secondary and tertiary powers, where primary powers are those 'that cannot be defeated in war by any other state or coalition of states without exacting comparable costs from its opponents. ${ }^{10}$ Vital does not rely extensively on the size and power of a state as the dominant criteria for describing it as small or large. He rather uses behaviour that a state adopts and power it is able to project toward others. He illustrates this with the example of Czechoslovakia in 1938 which, according to Vital, caved in under a combined pressure of bigger powers and behaved like a small power. But if Czechoslovakian leaders had resisted pressure, or if they had resisted successfully, the argument goes that it certainly would not be perceived as a small power. ${ }^{11}$

Jeanne A. K. Hey makes a clear statement that no consensus on the acceptable definition should not prevent us from discussing 'smallness'. According to her, what obstructed the development of small state foreign policy theory is the fact that students of small states' behaviour researched them within one of the three possible clusters of small states: micro states, small states in the developed world, and small states in the so-called third world. Thus, scholars remained limited to one of the above categories and have reached conclusions that were applicable only to narrow groups of states. Instead of insisting on precise and generally applicable definitions, Hey uses the concept of small states. The concept that she and her associates have opted for is the one that is based on the perception of the state, and the self-perception of the state's leaders and population about their position in the international hierarchy. In other words, if a state's leaders and its

7 Long 2017.

8 Browning 2006; de Carvalho and Neumann 2015; Ingebritsen 2002.

9 Krause and Singer2001, 15-25, 16.

10 Vital 1971, 15-29, 15.

11 Ibid., 15-29, 17. 
population are convinced that they live in a small state, and/or if other states perceive it as a small state, it shall be considered as such. ${ }^{12}$

The dividing line between the two broad categories of definitions goes along different theoretical premises the authors acquired and applied in their research on small states. The most important implication of this division is whether states that are labelled as small have the capacity to overcome their power deficit - which they do, according to relative definitions - or they are permanently locked into a power hierarchy they cannot escape, which, according to absolute definitions, implies their dependence on big powers' protection. The most recent work on small states speaks in favour of relative definitions and opens up room for re-discussion of power in international relations.

\section{Discussions on 'Smallness' and Power}

Small states' scholars unavoidably had to deal with the concept and meaning of power. Authors who introduced relational definitions, by which they have established 'smallness' in relation to 'greatness', first had to introduce variables based on which smallness and greatness would be measured. Authors like Raymond Aron and Hans Mouritzen came up with the distinction between offensive and defensive powers, where the latter category naturally falls within the domain of small states. ${ }^{13}$ According to Mouritzen, the former means one's capability to influence the environment, while the latter refers to the ability to avoid being influenced by it. ${ }^{14}$ Other authors also discuss the changing nature of the manifestation of power, where the military power has become increasingly concentrated on the side of big states. They, however, seem to be lacking political power since it is becoming widely diffused. ${ }^{15}$

With a group of other authors, Laurent Goetschel analyses small states' security policies assuming that they stem from those states' security identities. Those identities, as presented by Goetschel, are constructed from the states' past historical experiences, and from myths and images that shape small states' leaders' perceptions of the roles their states play in the international system. If small states' security policies are understood in this way, power in its material form has only indirect influence on states' positions in the international system. Small states can adopt different foreign policy options, those that do not necessarily reflect their limited material base. This way, the power of small states is dependent on their foreign policies in a given international environment. ${ }^{16}$

12 Hey 2003, 2-4.

13 Raymond Aron, according to Bjol 1971, 29-39, 36; Mouritzen 1991.

14 Mouritzen 1991, 219.

15 Vandenbosch 1964.

16 Goetschel 1998, 13-31. 
There are a few important consequences of understanding power as connected primarily with the roles that the states' leaders have ascribed to the states they represent. First, although states' sizes and geographical positions are fixed, they are not necessarily determining the foreign and security policies to be employed, as that choice depends on the states' elites' understanding of their position and opportunities in a given international setting. If this is the case, then the role that a state plays as the identity provider for its citizens (which small states are believed to be in a better position to play, compared to many big states, because of a higher coherence of their policies and their high mobilisation potential), or its recognition as a cultural power, are ways for a small state to overcome its power deficits emerging from purely materialistic parameters. The second important implication is that identities that shape foreign policies are also not fixed, and could be changed with states' redefinition of their international positions, their opportunities, and their objectives in a given environment. If identities, as Goetschel claims, are based on past historical experiences, states' security objectives can be changed in the light of new historical experiences such as war or alignment. ${ }^{17}$ Based on their policy choices, small states can, in Goetschel's understanding, challenge their power deficits and act as nonsmall actors. This understanding challenges the traditional understanding of power, viewed as dependent on geography and size. Instead, power is understood to be multidimensional and to consist of economic strength, attractiveness of culture, scientific excellence, etc., but it is even more dependent on a state's ability to join international institutions as places where challenges and problems are dealt with. ${ }^{18}$ As a consequence, Heiner Hänggi argues, states that stay outside of international institutions are weaker or smaller in relational terms since they failed in their opportunity to enhance their external sources of power, meaning power coming from the interaction with others. ${ }^{19}$

The approach to defining smallness also reflects understanding of the international system as such. Vital's outdated measurement of the states' power, and their consequent categorisation in clusters of big and small, was relevant for the period in the international history when such a binary division made sense, and when security concerns of small states perfectly reflected their fears caused by such a division. However, in the multidimensional, integrated, globalised and complex agenda of today, such a division does not seem to reflect security concerns of either big or small states. Although criticised for offering a rather narrow definition of what makes a state small, Vital actually includes a rather broad list of elements in his definition of the power discrepancy between the states. Despite the fact that he relied heavily on material discrepancy in terms of size (territory and population), Vital also included elements such as geographic proximity, strategic attractiveness of one's territory, cohesiveness of the population, and internal support provided to government's policies. He defines a state's power as the capacity to either induce others to follow its preferred line of conduct or be able to withstand pressure coming from others. ${ }^{20}$ In the

17 Ibid., 25-31.

18 Von Däniken 1998, 43-49, 44.

19 Hänggi 1998, 79-97, 85.

20 Vital 1967, 87, 118-119. 
case of small states, the power is defined as the second alternative - the ability to withstand pressure or avoid situations where one's weaknesses would be apparent and exploited. Referring to this, Arne Olav Brundtland points that we have to take into account not just a state's power base, but also the object toward which a state is applying its power. ${ }^{21}$ In that respect, non-alignment might be perceived as a policy of hiding and escaping the attention of great powers (obviously applicable to the great-powers' rivalry during the Cold War), and its effects should be measured against that objective. Non-alignment, as discussed by small states students, is therefore a legitimate choice of states that is free of any moral content. ${ }^{22}$

An alternative view on how small states overcome their power deficits in relation to big powers, which is without any doubt a hierarchical relation, is analysed and presented in the volume edited by Benjamin de Carvalho and Iver B. Neumann. ${ }^{23}$ According to them, small states seek recognition from big powers by claiming their, albeit small, share in maintaining international peace and stability. This might come in the form of mediation in conflicts in which a particular small state has no direct interest in being involved, as was the case with Norway's diplomatic and donor involvement in the Middle East and the Balkans, or taking the lead in niche policies such as climate change, for example. Through their status seeking, small states do not wish to be recognised as big, but as good powers that often 'punch above their weight'. By doing this, according to the editors of the volume, small states do not compete with big powers, but rather with similar small states that often offer services and resources that exceed their power status. Norway, Sweden and Denmark are good examples of such states. They are small but economically powerful, and are often found in the roles of mediators in international crises and contributors to peacekeeping and peace-enforcement operations. Small states do not expect to be awarded a part of the status of great powers, but they do expect some of their status to be transposed to them. According to their analysis, the purpose of status seeking is the status itself, while how status translates to any other objective - be it greater power or more resources - is left to future studies. Although the content of power is shifting from military to other domains - economic, cultural and even moral, ${ }^{24}$ some states such as Norway, for example, successfully use their military capabilities as a status seeking tool. Nina Græger writes that Norway has proved to be able to provide relevant and timely capacities and resources for an operation that was highly relevant to a great power, and has in this way managed to convert its military potential, regardless of how limited it was, into social status. ${ }^{25}$ Even in cases when small states do possess significant military resources (an example of this is Finland), they do not necessarily transform them automatically into social status and influence. Græger claims that this is the reason why small states, unlike the bigger powers, are more often engaged in status seeking enterprises: because by doing so they might

21 Brundtland 1971, 195-215, 197.

22 Ibid., 195-215, 211-215.

23 de Carvalho and Neumann 2015.

24. Janne Haal and Matlary, according to de Carvalho and Lie 2015, 56-73, 65.

25 Groger 2015, 86-108, 101. 
get to claim influence and a place at the table, which is not something they could simply demand based on the size of their resources and capabilities.

However, although re-thinking and re-writing the concept of power seems to be unavoidably attached to the discussion of 'smallness' and small states' possibilities in the world politics, the framework of discussing smallness in terms of capacities, capabilities and power resources has been challenged only sporadically. Christopher S. Browning adopts a constructivist perspective in his analysis of contemporary small states with the intention to demonstrate that different discursive practices of stating what 'smallness' means, and how it can be interpreted, can imply different policy perspectives for small states. ${ }^{26}$ As he demonstrated in the case study of Finland, 'smallness' should not necessarily be interpreted as a hampering factor in the states' pursuit of their national interests. He points out that those states could - and Finland certainly does - tell the story of their 'smallness' in terms other than power and capabilities, thus turning their smallness into a comparative advantage in the international arena. As a consequence, a different narrative of 'smallness' could help build the identity of a smart and innovative power, one that can even claim grounds for a moral stake in international affairs.

Mouritzen dismisses all the attempts to explain the behaviour and policy of small states that rely on their 'smallness' (or weakness) in terms of size. Instead, he established his own research paradigm, where the main variable in the explanation of the foreign policy behaviour of small states is the constellation of relations in which small states find themselves within their immediate environments. In two basic sets of constellations, symmetric and adaptive acquiescence, ${ }^{27}$ states are affected in different ways by structural factors, i.e. relations between the big powers. Consequently, their policy responses to these changes differ. ${ }^{28}$

Clive Archer, Alyson J. K. Bailes and Anders Wivel also define small states by looking at the possibilities available to them within the framework of the international system. According to them, small states are those that cannot 'credibly threaten to leave, alter or destroy institutional structures: one important way in which their strategic challenges and options differ from those of great powers. ${ }^{29}$ Changes in that framework, such as the end of the bi-polar rivalry between the big powers, made room for active manoeuvring on the side of small states previously considered to be mere consumers and passive elements in the international setting. In the more favourable post-Cold War setting, focus on military power and military threats would necessarily limit our viewpoint to the areas where

\footnotetext{
26 Browning 2006.

27 In the symmetric constellation, a small state, or a weak power in Mouritzen's terminology, is in the roughly similar position to the two competing big powers in the system, while in adaptive acquiescence that relationship is asymmetric, with a small state being unilaterally dependent on its relation with one big power. Mouritzen 1991, 218.
}

28 Mouritzen 1991, 217-230.

29 Archer, Bailes and Wivel 2014, 9. 
small states have been traditionally the weakest. ${ }^{30}$ According to the above authors, small states should instead embrace a wider agenda that allows them to create more networks, find their niche security options, and focus on strengthening their internal societal and political cohesion instead of embracing the big powers' security agendas.

In the introduction to their collection of the most influential works on small states, Iver Neumann and Sieglinde Gstöhl explain the position of 'middle powers' in international relations. This term, in their view, means that some states have achieved 'greatness' only in certain areas, hence stopping short of (according them) the big power status. They thought Sweden was a good example of this term, as it is a state that is unquestionably strong in many respects, such as internal cohesion and sense of self, but whose limited material resources of power will never let it achieve successes in many areas that could lead it to a great power status. ${ }^{31}$

In short, the disagreements on possible definitions of small states do not exist just in relation to the two broad categories, as defined above, but also revolve around the understanding of power or the projection of power. The definition of 'smallness' and how power understood in materialistic terms relates to the 'real' power is relevant not only because it reflects the theoretical background of the respective authors. It is relevant also because it points to their understanding of whether a small state is locked into a hierarchy of states according to its power, or the structure of international system is more diffuse opening many possibilities for small states to pursue different policy options. While there is a dominant understanding of power as relying on material elements, such as size of the territory and human and economic resources, there are some attempts within the small states literature that aim to challenge this rather simplistic understanding. Common for those attempts is the intention to connect power with the capacity of projecting one's will in relation to other actors in the international arena. Although that capacity is necessarily linked to the power base, it could not be simply equated with it; instead, scholars also have to take into account various webs within which small states operate. Joining alliances or staying away from them are two starkly different courses of small states' foreign policy action which have been extensively discussed in the literature. It is to this issue that the article now turns.

\section{Small States Inside and Outside of Alliances}

Much attention has been devoted to small states engaged in the alliances and to those that opted to stay outside of formal contractual relations with other states. There is not even an agreement on a precise definition of what alliances are, which some authors find to be a major drawback in the construction of the comprehensive theory of alignment. ${ }^{32}$ Heinz

30 Ibid., 7.

31 Ingebritsen, Neumann, Gstöhl and Beyer 2006, 8.

32 Krause and Singer 2001, 16. 
Gärtner proposes one plausible definition, according to which 'alliances can be defined as formal associations of states bound by the mutual commitment to use military force against non-member states to defend member states' integrity. ${ }^{\prime 3}$ A similar but even looser definition of alliances is offered by Stefan Bergsmann, who defines alliance as 'an explicit agreement among states in the realm of national security in which the partners promise mutual assistance in the form of a substantial contribution of resources in the case of a certain contingency the arising of which is uncertain.34 ${ }^{34}$ The difference between the two proposed definitions is certainly in the formality attached to the mutual agreement between the states that make a commitment to each other. The second definition narrows the area of cooperation to the issues of national security, which helps with the research of small states' position towards alliance membership from the point of view of their security policies. The second definition also avoids the extensiveness of the term 'integrity' and points directly to the uncertainty of events for the sake of which the alliance is formed. Both authors, however, move away from the classic definitions of alliances previously proposed by George Liska, who equalled alliances and alignments since both represent formal associations between two states against a threat represented by a third, more powerful state. ${ }^{35}$ Stephen Walt also makes no distinction between alliances and alignments, keeping the definition clearly in the realm of security cooperation by defining the above as formal or informal agreements on security cooperation between two or more sovereign states. ${ }^{36}$

According to alignment theorists, the typical dilemma of small states to either join an alliance or stay outside any formal contractual relationships with other states is the one between 'entrapment' and 'abandonment'. This is a dilemma that involves two uncomfortable possibilities: the first is fear that, speaking from the position of small states, they would be lured into conflicts they would otherwise be able to avoid and in which they do not have any particular interest to defend. On the other side, if they opt to stay outside of those formal relations, they face jeopardy of being left alone or abandoned. ${ }^{37}$ This dilemma, in terms of the security agenda of the 21st century, in which membership in international organisations is a dominant feature, could also be presented as a conflict in the small states' pursuit of influence $v s$. autonomy. As pointed by Goetschel and Baechler, the more influence small states achieve over their bigger counterparts, the less autonomy they have and vice versa. ${ }^{38}$

Similarly, Vital claims that full consequences of small states' vulnerabilities, or rather the effects of relying on one's own assets, are shown precisely when small states stay outside of the alliances' protection. Furthermore, those are the only situations, according to Vital,

33 Gärtner 2001, 1-9, 2.

34 Bergsmann 2001, 25-37, 26.

35 Liska 1962.

36 Walt 1987.

37 See also Goetschel 1998, 26.

38 Baechler 1998, 267-285, 271. 
when a state is acting alone and exercising its own foreign policy which could be compared to the foreign policies of big states. ${ }^{39}$ At the same time, he is rather pessimistic about the prospects of non-alignment as a viable option for small states. That is because their limited capacities make even the smallest defeats in the foreign policy arena a significant loss that is almost certainly jeopardising the states' vital interests while severely constraining their room for manoeuvre. At the same time, he is not an advocate of small states entering alliances with powerful actors, as in such arrangements they will find themselves to be minor partners dominated by bigger counterparts and forced to make concessions.

In Vital's view, the choice of strategy that a state will eventually pursue depends on two core factors: the assessment of its external environment and base and the total pool of its material and human resources. In addition, the choice of strategy also depends on the character of its leaders (which, according to Vital, is even truer in the case of small states), characteristics of the state's population, and their value orientation. ${ }^{40} \mathrm{He}$ classifies possible strategies into two broad groups: active, aiming to change the position of a small state in its external environment, either by increasing the state's material and human base or trying to change the imbalance of power in other ways, and passive, aiming to preserve the status quo. Non-alignment is certainly a defensive strategy. Similarly to scholars who discussed the feasibility of non-aligned states' military postures, Vital also insists on viable deterrence capacities of a state as crucial for its survival. As well as others, he believes that the most plausible strategy of a small state when confronted with the possibility of being attacked by a powerful state is to make the attack as costly as possible, thus making a likely that the oppressor will consider alternatives. While discussing the range of limitations small states face while defining and conducting their foreign policies, such as constraining economic base, administrative and intelligence resources, Vital still finds that small states have some advantages, and they are higher coherence and popular support of their policies. Since small states operate with a narrow scope of resources and face a limited number of problems, they are assumed to be able to achieve higher coherence in their policies as well as higher popular support, since the majority of foreign policy and security challenges they face might pose a challenge to national survival. This has to be updated with data from the present security agenda, where small states do not necessarily face threats to their survival. Contrary to this, they are able to find niche opportunities to exercise their comparative advantages and contribute to international peace.

In contrast to this assessment of alliances and their usefulness for small states, which reflected threats emerging from the Cold War rivalries, Simon W. Duke reassesses their validity in light of the changed post-Cold War security agenda. He claims that in the absence of immediate external threats alliance membership lost its previous relevance for small states. Since most threats - as proved by the political instabilities in the Balkans and Caucasus - emerge from the states' internal weaknesses, membership in alliances does not seem to serve as a valid response to these types of threats, nor is there any interest

39 Vital 1967.

40 Ibid., 122. 
for the alliances' big member states to engage in such conflicts. Duke points out that the changed nature of security threats now carries a different cost-benefit analysis for small states. $^{41}$

Jean-Marc Rickli discusses security and military options of small neutral states and how they have to adapt their military forces in order to appear as credible actors in the international peace keeping operations and within the framework of cooperative security. In his own account, the author belongs to the fourth generation of students who are interested in the security of small states. ${ }^{42}$ He discusses the dynamics of relations between states while analysing the power that can be mobilised and exercised - not 'real' material power, as understood by realists. According to him, small states have a choice of either preserving their autonomy, i.e. when they opt for the policy of neutrality, or exercising their influence, and that it is when they become members of alliances and actors in cooperative security. According to Rickli, small states cannot do both at the same time, since only big powers have sufficient resources to do so. He concludes that cooperative security is actually the only security option for small states nowadays, due to the types of threats the world is facing. ${ }^{43}$ An input into the debate on the level of autonomy that small states might have as alliance members was given by Ann-Sofie Dahl and Norman Hillmer in 2002. They discuss whether there was room for an independent foreign policy within NATO, and how small states participate in the decision-making in the Alliance. ${ }^{44}$ Based on the accounts of Swedish and Finnish neutrality, they elaborate the ambiguities of the neutrals' relations with both NATO and the EU. In both cases, pragmatism prevailed and accommodated these countries' historical legacies with benefits offered by the EU membership and cooperation with NATO.

While there is a consensus that small states are more exposed to constraints coming from the international environment than big ones, there is also an agreement that they show more interest in supporting international norms and multilateral approach to the international problems. This is because the respect for principles in the international fora. is something that can protect them from the aggression of more powerful states. Sporadically, there is an expectation that small states might act as moral arbitrators in the international arena, precisely because they demonstrate high respect of, and attachment to, principles and norms. In other words, since they cannot play power politics they are viewed as those who can act with sound moral judgment in international affairs.

41 Duke 2001, 39-51, 50.

42 In Rickli's account, the first generation of small states students adopted a definition based on quantitative criteria (size of population and territory). The second generation looked at small states and their place in the international system. The third generation adopted a psychological definition, where smallness was defined by self-perception of small states' leaders. In this account, he belongs to the fourth generation of small states scholars who define small states according to the power they are able to mobilise and exercise. Rickli 2008, 308-309.

43 Rickli 2008, 307-325.

44. Dahl and Hillmer 2002. 


\section{How to Study Small States' Security Policies?}

The majority of authors who discussed security options that are available to small states undoubtedly found structural reasons to be the dominating explanatory variable for their policy choices, while the appropriate level of analysis is the international system. Vital's work is no exception in this respect. Although he allows some room for factors such as the states' leaders, general national feelings and values attached to it, the dominant factors in his analysis are still the external environment and constraints emerging from it. Although scholars working from the realist and neo-realist perspective agree unanimously that it is the structural reasons that determine small states' foreign policy choices, some of them leave room for a more or less free choice that small states have while operating under structural constraints. In other words, while it is the big powers and their mutual relations that define the international structure and set the tone of international relations (whether conflict-prone or allowing for some form of cooperation), small states still have the luxury of choosing between the few policy options that are available to them and are applicable in a given environment. ${ }^{45}$ This might lead to deeper interest into how small states' decision makers actually decide among different policy options, and which factors account for those decisions.

However, several authors argue that small states' domestic politics and internal political dynamics might also account for their behaviour in international affairs. Hence, Miriam Fendius Elman challenges neorealism in its own playground, or at least what neorealist authors claim to be their domain - fitness to explain states' foreign policy behaviour and their security policies. ${ }^{46}$ She demonstrates the applicability of institutionalism in explaining domestic institutional reforms which are often tailored to respond to external pressures to which new states are especially exposed. Apart from having been able to demonstrate connections between international pressures and domestic institutional arrangements as one possible line of investigation she, however, has not demonstrated the dominance of the domestic level of analysis in the study of small states' behaviour.

Besides being exposed to external constraints more than big states, small states are also believed to have a lower level of international involvement, while their actions have limited potential to create consequences for other members of the international system. ${ }^{47}$ Ulf Lindell and Stefan Persson discuss the disproportional influence that small states demonstrate in international affairs under the label of 'small state power. ${ }^{\prime} 8$ What they have found while systemising the discussions on small states in world affairs is that such studies could be grouped into two broad categories. The first encompasses all the discussions that ascribe the performance and security of small states either to the structure of the international system, the state of the system (nature of relations between big powers) and

45 Baker Fox 1959; Väyrynen 1997, 41-77.

46 Elman 1995.

47 Barston 1971, 39-57, 41.

48 Lindell and Persson 1986. 
international norms, or the small states' qualities, such are their geographical position, reputation, material and human resources, and specific relations with other states. The second group of studies includes works that investigate small states' tactics and policies, bringing the discussion to the small states' power phenomena. Those policies include nonalignment, the policy of taking advantage of big powers' disputes, or any other specific behaviour that small states employ. The most interesting point that appeared as a result of this exercise is the distinction between the power of small states that came out of their active influence, their purposeful actions, or as a consequence of any of the small states' internal features.

Hey and her associates do not take for granted the dominance of either external pressures or domestic dynamics, but instead conduct an empirical investigation of a number of small states' cases in order to discover the appropriate level of analysis for the study of their foreign policy behaviour. Their research reveals a dominance of structural factors such as the presence of regional hegemons and power dynamics in their respective regions. Only under certain circumstances, and when structural reasons allow it, domestic politics and the roles of individuals emerge as a factor of influence. As it appeared, the latter factor is particularly relevant in a number of less developed small states. Their research supports the general agreement in the literature on small states that they favour acting through international organisations and multilateral fora. This is efficient, however, only in the areas where major powers are willing to act multilaterally. ${ }^{49}$ Despite the prominence of factors such as internal political dynamics and impact of states' leaders, the work of Hey and her associates actually confirms the firm dominance of structural factors as resolute definers of small states' foreign policies. According to their research, domestic politics and personal imprint can make a difference only in the style and manner of conduct of policies that are always predefined by a set of external constrains.

Although the dominant interest in the existing literature has been in the international behaviour of small states, their internal characteristics, at least to a degree that they are relevant for their foreign policy posture, have also been discussed. The authors discussing small states' internal features mostly found weaknesses in the administrative and institutional capacities for formulating and conducting small states' foreign policies. This is followed by the lack of intelligence resources and a narrow span of international issues that can be properly covered, governmental pervasiveness, bigger impact of personalities, and narrow professional autonomy of administration compared to what is found in big states. ${ }^{50}$ All of these are specific features of political systems in small states. At the same time, smallness of a state, according to the same group of authors, could have a positive impact on the coherence of policies since they are believed to more often have homogeneous societies, which is a rare feature of bigger states. Smallness also allows states' administrative apparatuses to focus on a smaller number of problems, compared to

49 Hey 2003, 185-195.

50 Sutton 1987, 3-26. 
bigger states whose diplomacy continuously has a wider range of problems to focus on. ${ }^{51}$

Although the dominant level of analysis is global, several authors pointed that smallness has different comparative values if analysed at the regional and global level. ${ }^{52}$ While a state can be small in respect to its global ranking, it can also - and simultaneously - act as a big regional power and actually try to transmit the regional power potential to its global position. Furthermore, regional and global levels of analysis are sometimes unavoidably interlinked, where the case in point is the great powers' involvement in regional conflicts. In his review essay, commenting on Howards Wriggins's work on regional politics, Richard Ned Lebow writes that realist theories have difficulty explaining the influence that smaller states, or in his words lesser powers, exercise over great powers, which has been the case in the historical account of the USSR relations with India, Somalia and Vietnam, or the U.S. experience with Pakistan and Iran. Examples of these states exercising disproportional influence over greater powers are, according to Lebow, understandable only if we discuss power in relational terms and in terms of asymmetries. The most important asymmetries, according to him, are resources, interests, justice, alternative policy options, time pressure, reputation and willingness to suffer. Based on these asymmetries in a given context, smaller states can exercise influence over their bigger counterparts that is disproportional to their relative capabilities. ${ }^{53}$

Limited efforts have been invested into a discussion on the types of threats that small states face. This is mostly due to the fact that realists and neo-realists alike see external threats, pictured as either big neighbouring or potentially threatening power, or a clash between two or more big powers, as self-evident dominant threat to the security of small states. Jonathan Alford points out that it is their geographical position that might make small states pray to big powers, but only if the territorial conquest of a small state can provide the threatening power with an advantage in its competition with other big powers. In other words, big powers are not interested in 'hijacking' small states just because they are small and vulnerable if they do not have a strong incentive for such an endeavour. ${ }^{54}$

Insights into the internal fragility of small states and problems emerging from it provided in the collection of essays edited by Efraim Inbar and Gabriel Sheffer in 1997 are more interesting. ${ }^{55}$ Conceptually, their approach is developed around ethnic national states and the first question they raise is how struggles, actions and ambitions of these actors affect the international system. The levels of analysis are international and regional security. The authors find that the majority of threats for a small state come from its regional surroundings. The regional setting is at the same time the level at which the consequences of irredentist and secessionist actions of ethnic groups lead to instability, posing the most

51 Bjol 1971, 29-39, 30.

52 Goetschel 1998, 13-31, 27.

53 Lebow 1997.

54. Alford 1984.

55 Inbar and Sheffer 1997. 
serious threat to regional security. According to the authors, security challenges of small states did not cease to exist with the end of the great power rivalry. Although they are currently not exposed to dangers emanating from the international system characterised by the clash of great powers, small states however are exposed to hostile ethnic neighbours and regional hegemons. The contributors to this volume find realism to be of limited usefulness in providing an explanation of the behaviour of small states since their leaders do not always necessarily behave in a rational manner.

\section{Conclusion}

There are three major points that emerge from the review of small states literature. First, there is the expectation that in their foreign policy behaviour small states demonstrate features that are common to the majority of states within the same group, and which are different from the behaviour of big states. One of those features is a tension or dilemma attached to the alignment policy and fear that, speaking from the position of small states, they would be lured into conflicts which they would otherwise be able to avoid and in which they do not have any particular interest to defend. On the other hand, if they opt to stay outside of those formal relations, they are in jeopardy of being left alone or abandoned. ${ }^{56}$ Second, small states are vulnerable, more than their bigger counterparts, to insecurities emerging from the structure of the international system and have limited options, and less room for mistakes in mitigating those insecurities.$^{57}$ Finally, small states are expected to favour multilateral frameworks in the arena of international security and to show more support for international norms and institutions that will protect them from whims and intentions of more powerful states..$^{58}$

As for the question of the current state of affairs in the small states' studies, it appears that most of the literature on small states is centred on the issues of their mere existence as a phenomenon of their own, rather than on discussing why and when 'smallness' matters, and which security problems emerge from it. The authors discussing 'smallness' in the materialistic sense of the word - states that have smaller territories, populations and resources they can employ in relational terms measured to big states - obviously found them to be under threat of survival and exposed to many constraints coming from the international setting. While big states are those that give a tone to the international context, be it conflictual or cooperative one, small states are those that suffer consequences of their actions and have limited strategic options available to them. Scholars who studied neutrality as a strategic option usually employed by small states naturally came to discuss their security options in the alignment $v s$. non-alignment choice. Both choices bring their own fears to small states: that they will either fall victim to big powers' politics or remain exposed and alone.

56 Baechler 1998, 267-285.

57 Baker Fox 1959; Väyrynen 1997, 41-77.

58 Hey 2003. 
Still, this discussion does not bring much to the overall conceptual discussion on small states since there is nothing novel in the small states' behaviour, as pictured by alignment theorists and non-alignments students, compared to big states. In those accounts, they seem to behave as utility-maximisers operating on the basis of a clear cost-benefit analysis. This became even more apparent with authors occasionally stating that there is actually no significant difference in the behaviour of big and small states. ${ }^{59}$ If that is so, does their 'smallness' feature as an additional variable, or does it only point to their material limitations? Several authors discussing small states concluded that smallness was not the dominant feature in the states' political, economic and security endeavours. Smallness, according to them, was just another characteristic in the case studies of explored small states whose policies had to be researched within concrete context settings. No specific 'politics of smallness' was found and no specific set of problems that only small states face was identified. ${ }^{60}$

Only with the work of authors that brought in the identity-based politics, which accounts for states as identity-providers for their citizens and performers of specific roles in the international setting, did the discussion on small states open up to the possibility of their overcoming the power hierarchy and the dichotomy of small $v s$. big. The discussion on small states' security policies in the broadened security agenda of the 21st century opened up a question whether 'smallness' is indeed always a hampering factor, or small states might design their security policies in a more favourable fashion compared to their bigger counterparts.

In sum, the existing literature on small states still remains locked in the realms of realism and neo-realism and their perspectives on state security, with much of the emphasis being placed on the possibility of foreign aggression as the main threat faced by small states. While significant work has been done on updating the security agenda and broadening the list of security threats, small states literature does not seem to be able to catch up with these developments. ${ }^{61}$ This is needed not just for the sake of academic adjustments in the field but also because the updated research on small states and the main threats that they face today could provide a significantly different account of their future security policies. Further work in this field could be developed from case studies of specific small states situated in different contextual settings, which could reveal whether, when and how smallness happens to be a factor in foreign policy making and alignment policies. This could lead to a more profound conceptualisation of smallness and power, or lack thereof, of small states.

59 In his classification of primary, secondary and tertiary powers, Vital claims that tertiary powers are no different in their behaviour from primary powers and that they will not refrain from attempts to change their external environment. However, the difference lies in their ability to do so and the power potential they can employ for their pursuits. Vital 1971, 20.

60 Clarke and Payne 1987, 225-228. Hey is in line with this when claiming that a small state, Ecuador in her own research, can demonstrate a wide variety of behaviours employed in response to external circumstances. While smallness certainly is one of the factors directing a state's behaviour in each particular case, we cannot take for granted that its influence was applied in the same manner in all research cases. Hey 2003, 6.

61 Buzan1991; Paris 2001. 


\section{References}

Alford, Jonathan. 1984. "Security Dilemmas of Small States". The World Today 40 (8/9): 363-369.

Archer, Clive, Alyson J. K. Bailes and Anders Wivel, eds. 2014. Small States and International Security: Europe and Beyond. London: Routledge.

Barston, Ronald. 1971. “The External Relations of Small States”. In Small States in International Relations, edited by August Schou and Arne Olav Brundtland, 39-57. Stockholm: Almqvist \&Wiksell.

Baechler, Gunter. 1998. "Future Relevance and Priorities of Small States". In Small States inside and outside the European Union, edited by Laurent Goetschel, 267-285. Boston: Kluwer Academic Publishers.

Baehr, Peter R. 1975. "Small States: A Tool for Analysis". World Politics 27 (3): 456-466.

Baker Fox, Annette. 1959. The power of small states: diplomacy in World War II. Chicago, Ill.: University of Chicago Press.

Bauwens, Werner,Armand Clesse and Olav F. Knudsen, eds. 1996. Small states and the security challenge in the new Europe. London: Brassey's.

Bebler, Anton. 1992. "The neutral and non-aligned states in the new European security architecture”. European Security 1(2): 133-143.

Bergsmann, Stefan. 2001. "The Concept of Military Alliance”. In Small States and Alliances, edited by Erich Reiter and Heinz Gärtner, 25-37. New York: PhysicaVerlag Heidelberg.

Binter, Josef. 1985. "The Actual and Potential Role of Neutrality In Search of Peace and Security”. Security Dialogue 16 (4): 387-398.

Bjerga, Kjell Inge, and Torunn Laugen Haaland. 2010. "Development of Military Doctrine: The Particular Case of Small States”. Journal of Strategic Studies 33 (4): 505-533.

Bjol, Erling. 1971. “The Small States in International Politics”. In Small States in International Relations, edited by AugustSchou and Arne Olav Brundtland, 29-39. Stockholm: Almqvist \&Wiksell. 
Browning, Christopher S. 2006. "Small, Smart and Salient? Rethinking Identity in the Small States Literature”. Cambridge Review of International Affairs 19 (4): 669-684.

Burton, John W. 1965. International relations: a general theory. Cambridge: Cambridge University Press.

Buzan, Barry. 1991. People, States and Fear: An Agenda for International Security in the Post-Cold War Era.Harlow: Longman.

Clarke, Colin, and Tony Payne, eds. 1987. Security and Development in Small States. London: Allen and Unwin.

Dahl, Ann-Sofie, and Norman Hillmer, eds. 2002. Activism and (non)alignment: the relationship between foreign policy and security doctrine. Stockholm: Swedish Institute of International Affairs.

de Carvalho, Benjamin,and Iver B. Neumann, eds. 2015. Small States and Status Seeking: Norway's quest for international standing. London and New York: Routledge.

de Carvalho, Benjamin, and J. Harold S. Lie. 2015. "A great power performance: Norway, status and the policy of involvement". In Small States and Status Seeking: Norway's quest for international standing, edited by Benjamin de Carvalho and Iver B. Neumann, 56-73. London and New York: Routledge.

Duke, Simon W. 2001. "Small States in European Security”.In Small States and Alliances, edited by Erich Reiter and Heinz Gärtner, 39-51. New York: PhysicaVerlag Heidelberg.

Elman, Miriam Fendius. 1995. “The Foreign Policies of Small States: Challenging Neorealism in Its Own Backyard”. British Journal of Political Science 25 (2): 171-217.

Goetschel, Laurent, ed. 1998. Small States inside and outside the European Union, Interests and Policies. Boston: Kluwer Academic Publishers.

Grceger, Nina. 2015. "From Forces for good to forces for status? Small state military status seeking”. In Small States and Status Seeking: Norway's quest for international standing, edited by Benjamin de Carvalho and Iver B. Neumann, 86-108. London and New York: Routledge.

Gärtner, Heinz. 2001. "Small States and Alliances”. In Small States and Alliances, edited by Erich Reiter and Heinz Gärtner, 1-9. New York: Physica-Verlag Heidelberg. 
Hey, Jeanne A. K, ed. 2003. Small states in World Politics, Explaining Foreign Policy Behavior. Boulder, London: Lynne Reinner Publishers.

Hänggi, Heiner. 1998. “Small State as a Third State”. In Small States inside and outside the European Union, Interests and Policies, edited by Laurent Goetschel,79-97. Boston: Kluwer Academic Publishers.

Inbar,Efraim,and Gabriel Sheffer, eds. 1997. The national security of small states in a changing world. London: Frank Cass.

Ingebritsen, Christine. 2002. "Norm Entrepreneurs: Scandinavia's Role in World Politics". Cooperation and Conflict: Journal of the Nordic international Studies Association 37(1): 11-23.

Ingebritsen, Christine, Iver Neumann, SieglindeGstöhl and Jessica Beyer, eds. 2006. Small States in International Relations. Seattle: University of Washington Press.

Joenniemi, Pertti. 1988. "Models of Neutrality: The Traditional and Modern". Cooperation and conflict 23 (2): 53-67.

Joenniemi, Pertti. 1993. "Neutrality beyond the Cold War", Review of International Studies 19 (3): 289-304.

Karsh, Efraim. 1988. Neutrality and small states. London: Routledge.

Keohane, Robert O. 1969. “Lilliputians' Dilemmas: Small States in International Politics”. International Organization 23 (2): 291-310.

Krause, Volker, and J. David Singer. 2001. "Minor Powers, Alliances, and Armed Conflict: Some Preliminary Patterns". In Small States and Alliances, edited by Erich Reiter and Heinz Gärtner, 15-25. New York: Physica-Verlag Heidelberg.

Lebow, Richard Ned. 1997. "Small States and Big Alliances". The American Political Science Review 91 (3): 705-709.

Lindell, Ulf, and Stefan Persson. 1986. "The Paradox of Weak State Power: A Research and Literature Overview”. Cooperation and Conflict XXI: 79-97.

Liska, George. 1962. Nations in Alliance: The limits of Interdependence. Baltimore: The John Hopkins Press.

Long, Tom. 2017. "It's not the size, it's the relationship: from 'small states' to asymmetry”, International Politics 57: 144-160. 
McSweeney, Bill. 1987. "The Politics of Neutrality: Focus on Security for Smaller Nations". Security Dialogue 18(1): 33-46.

Mouritzen, Hans. 1991. "Tension between the Strong, and the Strategies of the Weak". Journal of Peace Research 28 (2): 217-230.

Möttölä, Kari. 1988. The Arctic challenge: Nordic and Canadian approaches to security and cooperation in an emerging international region. Boulder: Westview Press.

Ogley, Roderick. 1970. The theory and practice of neutrality in the twentieth century, 1904-1994. London: Routledge \& Kegan Paul.

Ørvik, Nils. 1971. The decline of neutrality 1914-1941: with special reference to the United States and the Northern neutrals. London: Cass.

Paris, Roland. 2001. "Human Security: Paradigm Shift or Hot Air?". International Security 26 (2): 87-102.

Reiter, Erich and Heinz Gärtner, eds. 2001. Small States and Alliances. New York: Physica-Verlag Heidelberg.

Rickli, Jean-Marc. 2008. “European small states' military policies after the Cold War: from territorial to niche strategies". Cambridge Review of International Affairs 21 (3): $307-325$.

Rothstein, Robert L. 1968. Alliances and small powers. New York: Columbia Univ. Press.

Schou, August, and Arne Olav Brundtland, eds. 1971. Small States in International Relations. Stockholm: Almqvist \&Wiksell.

Sutton, Paul. 1987. "Political Aspects". In Security and Development in Small States, edited by Colin Clarke and Tony Payne, 3-26. London: Allen and Unwin.

Vandenbosch, Amry. 1964. "The Small States in International Politics and Organization”. The Journal of Politics 26 (2): 293-312.

Väyrynen, Raimo. 1997. "Small States: Persisting Despite Doubts”. In The National Security of Small States in a Changing World, edited by Efraim Inbar and Gabriel Sheffer, 41-77. London: Frank Cass. 
Vital, David. 1971. "Analysis of Small Power Politics”. In Small States in International Relations, edited by August Schou and Arne Olav Brundtland, 15-29. Stockholm: Almqvist \&Wiksell.

Vital, David. 1967. The inequality of states: a study of the small power in international relations. Oxford: Clarendon.

Von Däniken, Franz. 1998. "Is the Notion of Small State still Relevant?". In Small States inside and outside the European Union, Interests and Policies, edited by Laurent Goetschel, 43-49.Boston: Kluwer Academic Publishers.

Walt, Stephen M. 1987. The Origins of Alliances. Ithaca and London: Cornell University Press.

Wolfers, Arnold. 1962. Discord and collaboration: essays on international politics. Baltimore: Johns Hopkins Press. 